\title{
Positivo/Natural: \\ sátira barroca e \\ anatomia política *
}

\author{
João Adolfo Hansen
}

\section{RESUMO}

Na sátira barroca atribuída a Gregório de Matos e Guerra (Bahia, 1682/1694), a ordem do conceito engenhoso dramatiza o conceito de ordem, segundo a doutrina neo-escolástica do corpo místico do Estado como vontade unificada no pacto de sujeição à persona mystica do Rei. Nele, os vários topoi teológico-políticos elaboram e confirmam o conceito moderno de poder soberano absoluto. Nâo são mera ornamentaçâo de uma retórica do poder "voltando" à Idade Média, muito menos oposição nacionalista, libertina, herética, etc. aos poderes constituídos, como o anacronismo costuma postular. Segundo a doutrina das duas pessoas do Rei, a sátira intervém na circunscriçâo do poder ordinário tendo por fundumento o poder absoluto da razão de Estado soberana. Providenciulista, é anamnese do Ditado: nela, o ius é sempre lei natural expressa em leis positivas - portanto, Razāo. Não se opõe ao privilégio, enfim, mas aos efeitos de seu excesso ou falta. O abuso é paixâo retoricamente efetuada, a que se opôe o bom uso pré-formado na vontade real, que a enunciaçâo prudente da persona satírica metaforiza.

Como técnica retoricamente regrada de enunciar a Lei na forma monstruosa dos interditos, confirmando o Um no misto e no múltiplo, a sátira barroca seiscentista atribuída a Gregório de Matos e Guerra encena a punição. Ao evidenciar publicamente no monstro moral que a paixão é pecado e que o pecado é uma culpa, propōe o remédio e o alívio de sua prudência política: teatro da persuasão e pastoral do remorso.

Referido à sátira, o termo política tem aqui o significado, corrente nos séculos XVI e XVII, de uma arte que, além de garantir a segurança da República contra seus inimigos externos, também cuida de sua concórdia interna, mantendo a ordem e a paz apesar das divergências de posiçōes e conflitos de interesses $^{1}$. Na chave típica do providencialismo ibérico que se opōe ferrenhamente a

\footnotetext{
* Este texto é parte de um capítulo de A Sátira e o Engenho (Um estudo da poesı barroca atribuída a Gregório de Matos e Guerra, Bahia, 1682-1694), apresentado como tese de doutoramento ao Departamento de Letras Clássicas e Vernáculas da FFLCH/USP, em 1988.

1 Cf. PILLORGET, R. - Le mouvement insurrectionnel comme pratique politique dans la France du XVè siècle. In: Théorie et pratique politiques à la Renaissance. XVIİè Colloque International de Tours. Paris, Librairie Philosophique VRIN, 1977. p. 106.
} 
Maquiavel, o termo também é tomado no mau sentido, significando uma arte de triunfar nas competições da Cidade através da dissimulação, da hipocrisia e de outros meios adequados à ocasião. O termo aplica-se, assim, tanto à caracterização de uma técnica de policiar o Estado, "primeira parte da moral" que visa a felicidade do bem comum, quanto ao jogo livre das paixões e à satisfação das ambiçōes pessoais servidas por diversos expedientes, arte de triunfar ${ }^{2}$.

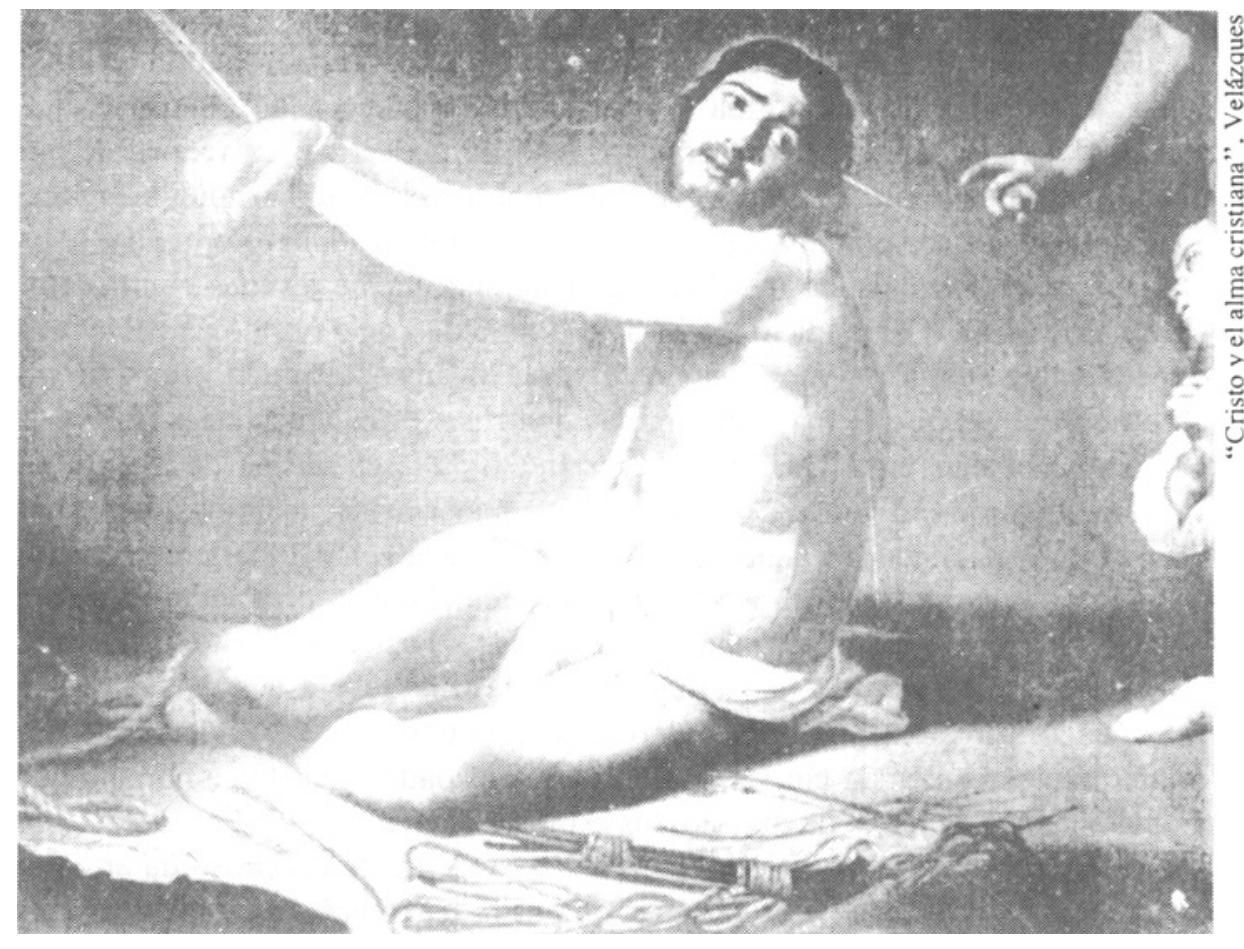

A sátira barroca seiscentista é política segundo esse duplo registro: funciona como uma técnica que hierarquiza metaforicamente a segurança da população, encenando seu controle no discurso e pelo discurso. Impondo normas aos corpos de linguagem, ela os interpreta como adequação ou desvio da lei positiva e natural de que se faz emissária, fundamentando a crítica, de direito, para a mesma população, a um tempo referencial e destinatário de sua intervenção. Ao propor a correção dos vícios - políticos no mau sentido referido - ela o faz em nome do ideal de bem comum ausente que a enunciação racional efetua, ditando a retificação do que expōe. Sua validaçāo é o Direito Canônico, principalmente em sua versão contra-reformista, que regula a hierarquizaçāo jurídica das práticas do Antigo Regime. Desta maneira, um de seus pólos de referência, lugar da unificaçāo e unidade ideais do bem comum, é a figura mística do Rei, sempre presente ainda quando não nomeado. Dele emana e para ele converge o sentido superior das açōes: à sombra da sua luz difusa e onipresente, a infelicidade e o erro das diferenças cobram sentido pleno, o de serem semelhanças próximas ou distantes de seu Um, senhor, sacerdote, pai, quase deus.

2 PILLORGET, op. cit., p. 106. É neste sentido, por exemplo, que se faz a sátira do Vigário L.ourenço Ribeiro contra Gregório de Matos. 
A mesma tensão do Um e do múltiplo metafóricos, rebatida nas variaçōes do mesmo e do_outro, do puro e do impuro, do permanente e do fugaz, sua intertradução contínua como antíteses unificadas precariamente em uma outra metáfora sempre diferida e fugidia, legíveis nos jogos do conceptismo engenhoso, têm aqui um de seus fundamentos. Cabe descrever sumariamente essa teologia política, para tentar evidenciar alguns princípios hierárquicos que na sátira constituem a persona como voz autorizada para falar.

Opondo-se à afirmação papista da plenitudo potestatis, relativizada e criticada pelos próprios contra-reformistas no século XVI, como Vitoria e Bellarmino, o Estado moderno afirma sua soberania ${ }^{3}$ incorporando contra Roma a mesma plenitudo potestatis na caracterização do poder real ${ }^{4}$. Trata-se de uma determinação teológica de novas estruturas políticas ${ }^{5}$ em termos de uma reatualização de doutrina, principalmente nos países católicos como Portugal e Espanha, em que a Escolástica reciclada pelos dominicanos e jesuítas contra-reformistas do século XVI e início do XVII é difundida como ortodoxia pelas instituições universitárias, como Coimbra, Évora, Salamanca, sendo o modelo não só do ensino de Direito mas também das doutrinas providencialistas do Estado monárquico então produzidas para fazer frente às teses ímpias de Maquiavel, Erasmo, Lutero, Calvino e Melâncton. Simultaneamente, mantidas as proporções desta generalização, a arte dita barroca do século XVII ibérico corresponde a uma reinterpretação de tópicas da Retórica clássica, principalmente Aristóteles, Cícero e Quintiliano, que são mantidas - basicamente, a elocução, reproposta como ornato dialético agudo - pela doutrina escolástica da analogia de atribuição e proporçāo com que então se interpreta o conceito engenhoso. Essa reinterpretação, operada em vários graus e intensidades, mantém a normatividade clássica dos gêneros, da divisão dos estilos e da verossimilhança, adaptandoa a novos fins. É ela que permite pensar o espetáculo maravilhoso da arte barroca como proliferação retoricamente ordenada em função da unidade de sua Causa Primeira implícita que, por isso, sempre efetua os vestígios do sagrado, mesmo quando cortesã e programaticamente ornamental. A mesma reinterpretação já implicara, no século XVI, até certo ponto, a redução dos paradoxos maneiristas, depois que se tomaram convencionalmente ornamentais e previsíveis,

Cf. KANTOROWICZ, apud COURTINE, J. F. L'heritage scolastique dans la problématique théologico-politique de l'âge classique. In: MÉCHOULAN, H., org. L' État Baroque 1610-1652. Paris, VRIN, 1985. p. 110: "Sob a autoridade do Papa enquanto princeps et verus imperator, o aparelho hierárquico da Igreja romana (...) mostrou uma tendência de tornar-se o protótipo perfeito de uma monarquia absoluta e racional sobre uma base mística enquanto que, simultaneamente, o Estado manifestou mais e mais uma tendência de tornar-se uma quase Igreja e, em muitos aspectos, uma monarquia mística sobre uma base racional".

4 Por exemplo, na proposição de James I, da Inglaterra: "regem non a populo, sed immediate a Deo suam potestatem habere". É contra tal doutrina absolutista do direito divino que se opõe a versão dos contra-reformistas ibéricos, notadamente Suarez, que conceitua ( absọlutismo como quase alienação popular do poder em mãos do soberano. Tal ueterminaçāo teológica de novas estruturas políticas é que permite pensár a sacralizaçăo do poder, o ritual e o espetáculo próprios da arte barroca. Ela implića também, no mesmo Barroco, a posiçáo de defesa dos estilos "clássicos", como é o caso, por exemplo, do antimaneirismo de Vieira contra os dominicanos gongóricos e, ainda, do provincial da Cia. de Jesus, Muzio Vittelleschi, em relação aos sermôes de Gracián.

Cf. COURTINE, op. cit., 109.
Opondo-se à afirmação papista da plenitudo potestatis, relativizada e criticada pelos próprios contra-reformistas no século XVI, como Vitoria e Bellarmino, o Estado moderno afirma sua soberania incorporando contra Roma a mesma plenitudo potestatis na caract erização do poder real. 
ao binarismo sóbrio da tensão dos opostos e contradições da arte barroca. Os procedimentos maneiristas muitas vezes coincidiram com as sugestōes da situação política introduzida pela Contra-Reforma e, em Portugal, com o afunilamento beato que o Santo Ofício e a fortíssima censura intelectual impuseram. Assim, certos procedimentos artísticos foram apropriados pela máquina católica da propaganda da fé: por exemplo, o binarismo das antíteses, a construção geométrica do poema como oposição de sensivellinteligivel, que poetas portugueses e espanhóis desenvolvem como diluição de Camōes e Gôngora, sāc muito conformes com a piedade católica e seu dogma da natureza humana decaída. Da mesma maneira, a reciclagem do aticismo, com a valorização da clareza, é adaptada à propaganda ${ }^{6}$.

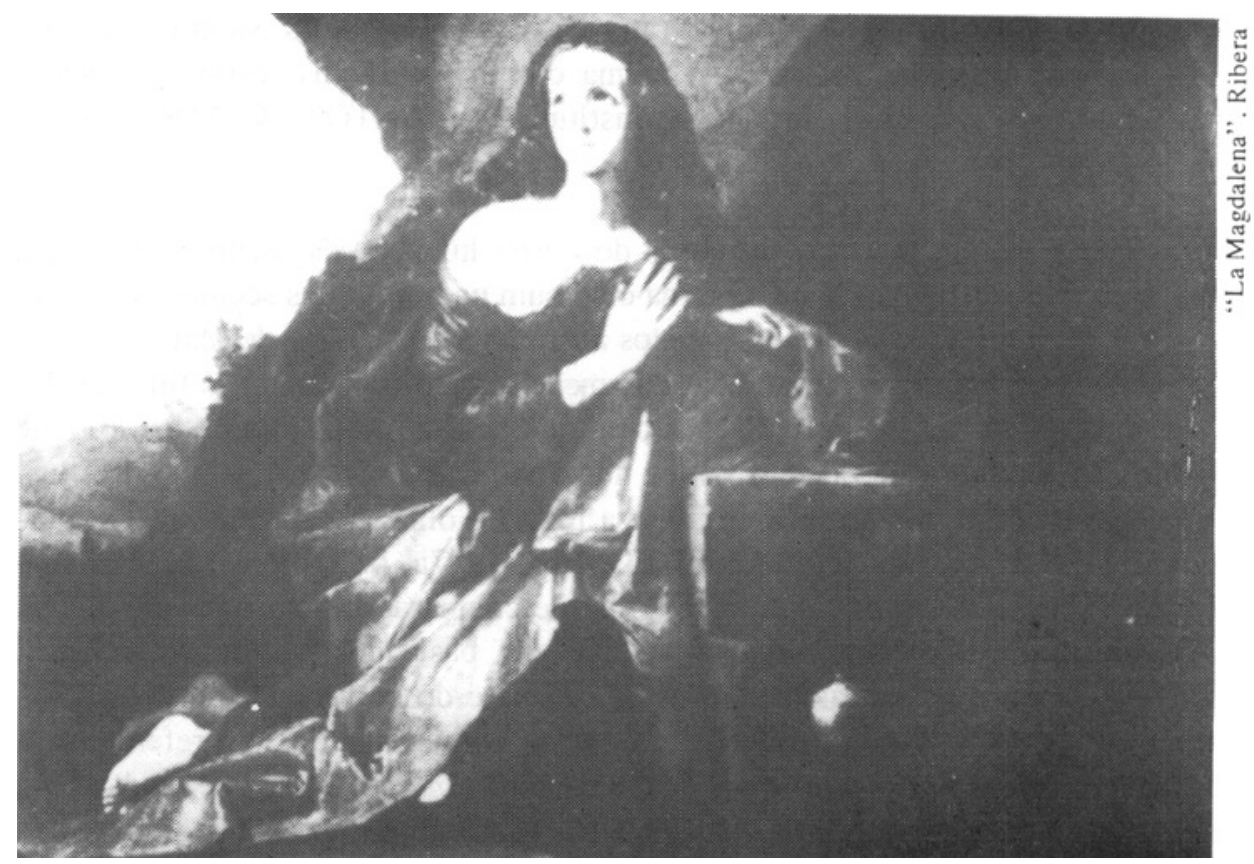

É a mesma reinterpretação que permite pensar também a defesa dos estilos clássicos, durante todo o século XVII ${ }^{7}$ : caso, entre outros, da posição de Vieira contra os gongóricos dominicanos, oposição artística cuja fundamentação é

6 A última sessão do Concílio de Trento, em 3 e 4 de dezembro de 1563, baixou algumas determinaçōes genéricas, que encontraram reciprocidade na arte sóbria e religiosa dos pintores da segunda metade do século XVI que se fazia em Roma antes das determinaçōes do Concilio. Estas especificavam que a finalidade das imagens religiosas é instruir os crentes e confirmá-los na prática de sua fé. $O$ uso de imagens que possam conter doutrina falsa ou encorajá-la é proibido. As imagens não devem encorajar a superstição. devem conformar-se às exigências da modéstia e da moderação: nenhuma imagem extraordinária ou de forma muito imprevisível poderá ser exposta na igreja sem permissâo do Bispo; etc. Cf. FREEDBERG, S. J. Painting in Italy 1500-1600. 2nd., London, The Pelican History of Art, 1983. p. 702.

7 Por exemplo, a partir de fins do século XVI, os jesuítas começam a lançar mão dos livros de emblemas como veículo pedagógico e propaganda da fé, substituindo os motes dos emblemas por apólogos e moralizando as imagens. Com o objetivo de substituir o herói pagão pelo cristão, a fábula mitológica pela parábola evangélica, a linguagem se adapta à Ratio studiorum, tornando-se clara, clássica. Cf. DOGLIO, M. L. Introduzione. In: TESAURO, E. Idea delle perfette imprese. Firenze, Leo S. Olschki, 1975. p. 11. 
teológico-política. Nela, o apelo às virtudes retóricas tradicionais da clareza, brevidade e verossimilhança visa a representação adequada da harmonia preestabelecida da Causa Primeira, como estilo natural que teologicamente alegoriza a escrita divina natural. Trata-se,. enfim, do que Tirso de Molina chama, em outro contexto, de política perfeiçāo. Para tratar dela é útil, portanto, um pequeno excurso escolástico.

Escolasticamente, a metáfora do corpo do Estado, presente nas letras do período, corresponde ao terceiro modo da unidade dos corpos exposto por Santo Tomás de Aquino em seu comentário do Livro V da Metafísica, de Aristóteles: unidade de integração, que não exclui a multiplicidade atual ou potencial. É o modo correspondente ao corpo humano:

"(...) quia eius perfectio integratur ex diversis membris, sicut ex diversis animae instrumentis; unde et anima dicitur esse actus corporis organici, idest ex diversis organis constitutis" (SANTO TOMÁS, 1957b, p.210-216).

Partes de um todo, os membros do corpo humano são instrumentos para um princípio superior, a alma. O tema é comum na poesia dos séculos $\mathrm{XV}, \mathrm{XVI}$ e XVII, lembrando-se aqui dois sonetos atribuídos a Gregório de Matos e Guer$\mathrm{ra}^{8}$. Unidade do corpo, pluralidade dos membros e diversidade das funçōes das várias partes são as três articulações com que Santo Tomás propõe o corpo, de modo que a integração de suas partes num todo härmônico é ordem: o pé é instrumento do olho, pois o leva de lugar a lugar; o olho, instrumento do pé, porque o guia em sua marcha (SANTO TOMÁS, 1957a, p. 210 e segs.). Por analogia, o corpus hominis naturale é termo de comparação com o corpus Ecclesiae mysticum: é o termo caput (cabeça) que, basicamente, efetua a relação. Analogicamente, assim, as metáforas da cabeça e do corpo humano podem nomear as partes superior e inferior de outros corpos analógicos: referem-se à Igreja como corpus Christi, à sociedade como ordinata multitudo e, ao homem, ser natural, como corpus naturale (SANTO TOMÁS, 1952). Transferido para a esfera política, o termo corpo mantém o significado da analogia teológica. A cabeça, sede da razão, é proporcionalmente, para o homem individual, o que Deus é para o mundo. Como o homem é naturalmente social, a semelhança com o universo não se encontra apenas no homem individual, mas também na sociedade regida pela razão de um só homem, o Rei, cabeça do corpo político do Estado (FERROL, 1957, p. 210 e segs.). O Rei está no reino assim como a alma está no corpo e Deus, no mundo. Como princípio regente da sociedade que analogicamente é um corpo, o Rei é sua cabeça ou razão suprema, que o dirige em função da integração de todas as suas partes e funções - enfim, da sua harmonia ou ordem. Pertencer ao corpo político do Estado implica, por isso, a imediata responsabilidade pessoal para com os demais homens, partes dele. Isto só se atinge pela concórdia, coincidência de todos quanto ao fím do corpo po-
Partes de um todo, os membros do corpo humano são instrumentos para um princípio superior, a alma. O tema é comum na poesia dos séculos XV, XVI e XVII.

8 Este topos, reciclado pela interpretação neoplatônica de Pico della Mirandola, no século $X V$, que em seu Heptaplus escreve haver encontrado toda a sabedoria de Moisés em cada verso de Moisés, retorna na poesia maneirista e barroca sob a forma de conceptismo engenhoso e lúdico. Cf., por exemplo, os dois sonetos de Gregório de Matos: "Entre as partes do todo a melhor parte" (OC-I - p.43) e "O todo sem a parte nāo é todo" (OC-1- p.44). 
lítico. Uma vez que pode ser imposta à força, porém, a concórdia não é suficiente se não houver também a concórdia de cada um consigo mesmo. É preciso reduzir a uma unidade comum da tranqüilidade da alma a diversidade dos apetites individuais que concorrem na situação social de concórdia (Id. ibid., p.215 e segs.) - em outros termos, as paixôes devem ser evitadas e controladas. Desta maneira, o modo de união mais perfeito do corpo político do Estado é a paz, como conformitas e proportio dos apetites 9 :

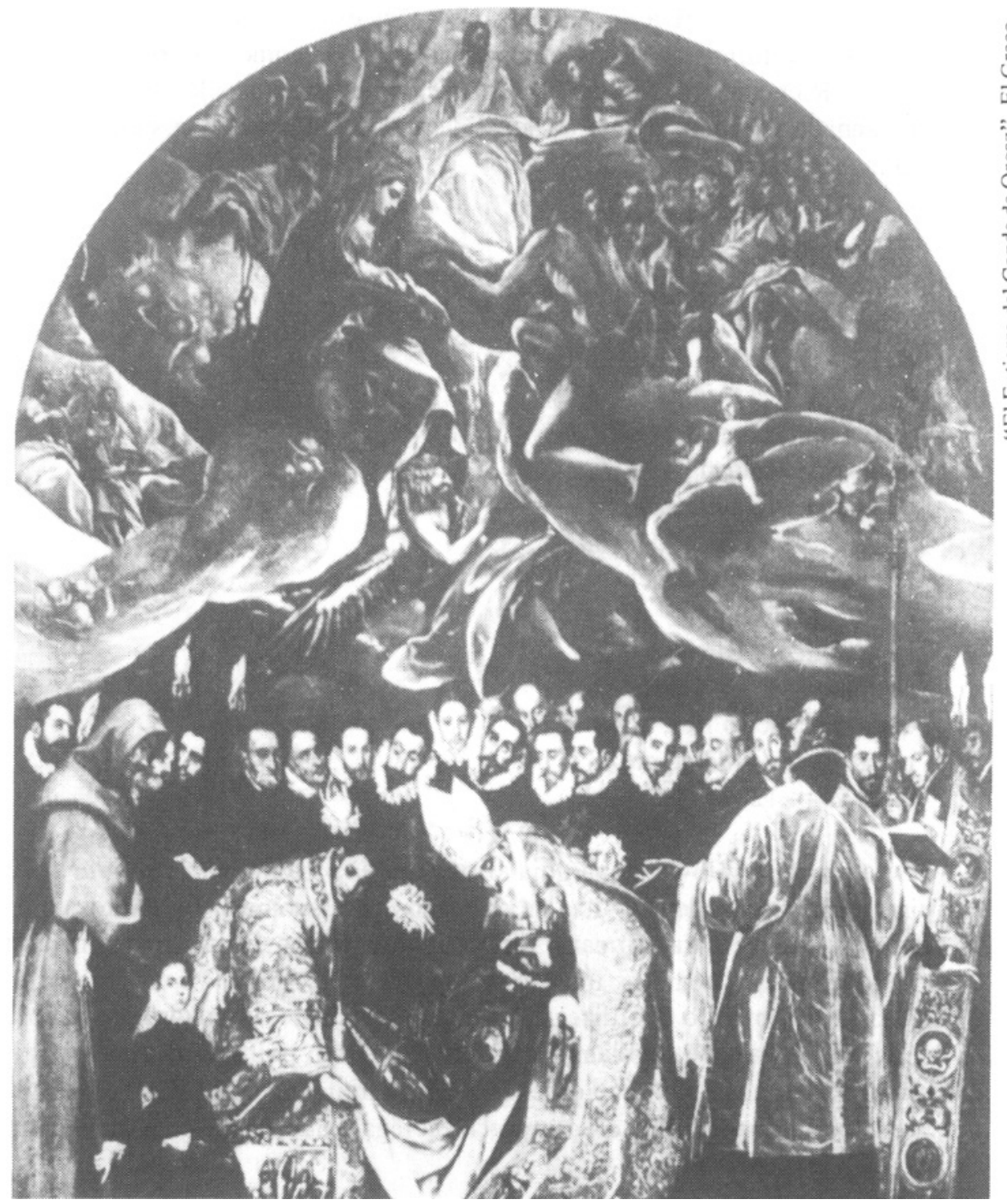

"Es el imperio unión de voluntades en la potestad de uno; si éstas si mantienen concordes, vive y cresce; si se dividen, cae y muere, porque no es otra cosa la muerte sino una discordia de las partes" (SAAVEDRA FAJARDO, 1957, p. 223).

9 Summa theolog. II-II, q. XXIX, a.1.: "Pax est tranquillitas ordinis; quae quidem tranquillitas consistit in hoc quod omnes motus appetitivi in uno homine conquiescunt". A paz implica, assim, o sossego interior e a uniāo dos apetites. (N.A.) 
No século XVII ibérico, a virtus lınitiva ${ }^{10}$ do amor do bem comum aparece traduzida na metáfora estóico-aristotélica da amizade, como se lê no mesmo Saavedra Fajardo:

'En las repúblicas es más importante la amistad que la justicia; porque, sì todos fuesen amigos, no serian menester las leyes ni los jueces; y aunque todos fuesen buenos, no podrian vivir si no fuesen amigos" (SAAVEDRA FAJARDO, 1976).

A enunciação satírica encena tais asserções escolásticas, recicladas pelos juristas contra-reformistas dos séculos XVI e XVII, como Vitoria, De Soto, Bellarmino, Ribadeneyra, Molina, Suarez, segundo os quais a legitimidade real é acompanhada inevitavelmente da legalidade das distinções e costumes que o próprio monarca não pode tocar:

"... eu com pura claridade

digo em literal sentido

que o Rei por Deus prometido

é: quem? Sua Majestade".

(OC-V-p. 1207)

(...)

"Logo em boa conseqüência

na Pessoa realçada

de Pedro está atenuada

desta Prole a descendência:

logo com toda evidência

e a luz da divina luz

se vê, que a Pedro conduz

o olhar, e ver de Deus,

que ao primeiro Rei, e aos seus

prometeu na ardente cruz."

(OC-V- p. 1208)

Se outro princípio da monarquia afirma que Princeps legibus solutus - "O Príncipe está livre das leis" - isto se dá menos para submeter os súditos ao arbítrio de um só que para afirmar o direito real de tomar iniciativas em matéria de poder legislativo, como os interesses do governo exigem. Por direito, assim, os súditos têm sempre o que dizer, desde que não saiam do quadro da lei posiliva e da lei natural que regulam a harmonia do corpo político. Basta-lhes, por exemplo, exaltar a lei para que defendam seus direitos e seus bens ${ }^{11}$, uma vez que a exaltaçāo corresponde a um reforço da legalidade, espécie de movimento

10 A sátira barroca encena a virtus unitiva da caridade e do amor como critérios da concórdia e da paz: "(...) para os bons sou inferno,/e para os maus paraíso" fala a Bahia personificada (OC-I- p.13); ou “(...) debaixo desta paz,/deste amor falso, e fingido/há fezes tão venenosas,/que o ouro é chumbo mofino" (OC-I- p.22). Veja-se que a persona satírica efetua a virtus unitiva como o que falta na Cidade, dominada pelo mal. Cf. SAAVEDRA FAJARDO, D. Empresas políticas. Ed. Quintin Aldea Vaquero. Madrid, Nacional, 1976, 2v. Cf. ainda, do mesmo Saavedra Fajardo, a "Empresa LXXXIX": "La ciudad que por la concordia era una ciudad, sin ella es dos y a veces tres o cuatro, faltándole el amor, que reducia en un cuerpo los ciudadanos."

11 Cf. COURTINE, op. cit., p.98-99. 
de adesão das partes do corpo à cabeça - o que também é uma chave para o dimensionamento político de tanta poesia encomiástica ${ }^{12}$, e da mesma sátira, como apologias da cabeça decisória:

\author{
"Porém Sua Majestade, \\ qual Príncipe Soberano, \\ que não se indigna de humano \\ sem dano da dignidade: \\ conhecida esta verdade, \\ que é verdade conhecida, \\ fará justiça cumprida, \\ para que se lhe agradeça, \\ que o mau na própria cabeça \\ traga a justiça aprendida." \\ (OC-I- p. 205)
}

Os temas entrelaçados da unidade do bem comum e da amizade das partes do corpo político são centrais na sátira barroca seiscentista, aliás, que os dispõe como oposição de mundo das relaçōes pessoais virtuosas (amizade) e, também, da ordem definida pelas relaçōes econômicas impessoais e viciosas, que tiram de si mesmas sua justificação, traduzido como "amor falso", "mortal ódio". É a metáfora corporal dessas relações pessoais de amizade do bem comum (como concórdia e paz) opostas ao ódio de sua ausência (como discórdia e guerra) que se dá na sátira como evento discursivo: comportamentos, atos, gestos, falas, metaforizados conforme elencos de vícios da tradição aristotélico-escolástica, figuram o mau funcionamento do corpo político.

Afinal, se a justiça não é de graça distribuída mas vendida em várias acepções do termo, é justiça bastarda - e da bastardia brotam frutos de corrupção. Veja, por exempio:
E grátis distribuída?... Vendida
Valha-nos Deus, o que custa, o que El-Rei nos dá de graça, que anda a justiça na praça, Bastarda, Vendida, Injusta."

"E que justiça a resguarda?... Bastarda

Que tem, que a todos assusta?... Injusta. (OC-I- p. 32)

\section{da unidade do bem comum e da amizade das partes do corpo político sāo centrais na sátira barroca seiscentista... \\ Os temas entrelaçados}

Segundo a articulação dos deveres recíprocos que ligam súdito e Estado, a sátira barroca ataca pessoas não exclusivamente por alguma peculiaridade que as faça imorais - afinal, somos todos filhos do mesmo Adāo - enquanto particula-

12 O gênero enconiástico, hoje ilegível, figura a potência, a sabedoria e o amor dos "melhores", segundo o modelo teológico da Trindade. 
res, mas pelo vício político que tal peculiaridade vem a ser como desordem na harmonia de todas as partes e o todo do corpo político, que se corrompe:

"Nem ao sagrado perdoam, seja Rei, ou seja Bispo, ou Sacerdote, ou Donzela metida no seu retiro.

A todos enfim dão golpes de enredos, e mexericos tão cruéis, e tão nefandos, que os despedaçam em cisco. Pelas mãos nada; porque não sabem obrar no quinto; mas pelas línguas nāo há leões mais enfurecidos." (CC-I- p. 22-23)

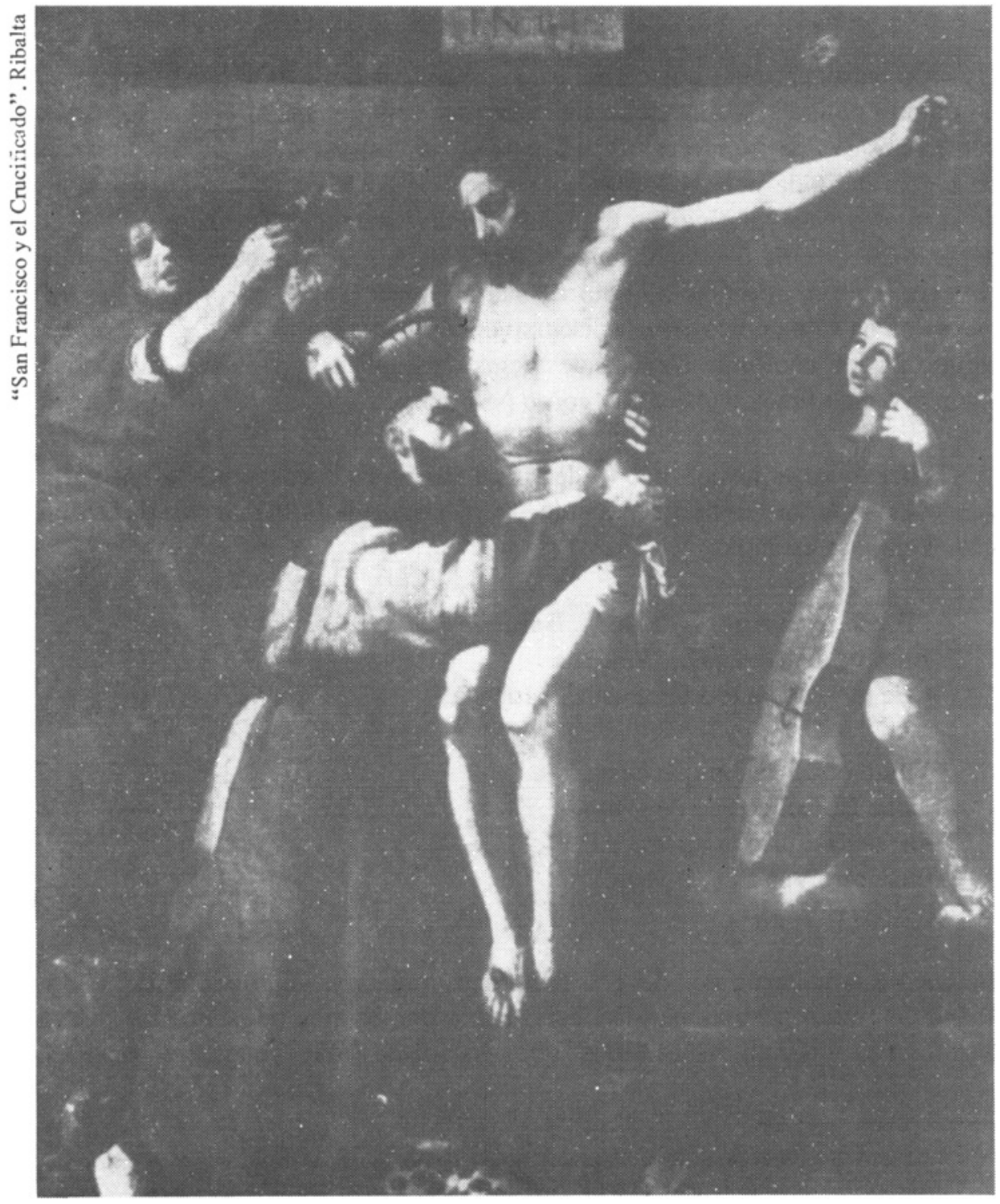


Assim, é mesmo a caridade cristã e, num nível abaixo, a amizade, que exigem que os maus sejam amputados do corpo da República, de modo que sua corrupção não contamine outros, virtuosos e honestos. Por isso, ainda, embora encene o imaginário fidalgo, a sátira é genérica, extensiva a todo o corpo político. A mesma sombria caridade agostiniana, em outra circunstância, propóe diretamente o amor ao próximo para a concórdia e a paz:

"Desejo, que todos amem, seja pobre, ou seja rico, e se contentem com a sorte, que têm, e estão possuindo." (OC-I- p. 28)

Dois elementos concorrem para a paz social do corpo do Estado, segundo tal doutrina: um é o da concórdia quanto ao bem comum e nāo aparente, sem o qual a paz é o "amor falso, e fingido" e "fezes tão venenosas"; outro é o da tranqüilidade da alma, ou sossego interno dos apetites de cada homem, sem a qual "todos pecam no desejo". O tema estóico, retomado do Sêneca do De tranquillitate animi, tem intensa circulação na literatura do século XVII, aliás, sendo adaptado ao desenvolvimento político de temas correlatos, como o do desengaño e o da concórdia ausente da sociedade vivida como teatro de enganos. A paz social do corpo do Estado, perfeita integração de suas partes e funções, combina a concórdia de todos no bem comum e a adesão de cada membro ao corpo político pelo controle da vontade ${ }^{13}$.

Os teóricos contra-reformistas, como Molina e Suarez, interpretam tal participação das partes no corpo pelo viés agostiniano da natureza humana enlutada pelo pecado original. A mesma sátira, como se viu, dramatiza tal crença:

"Uma só natureza nos foi dada:

Nāo criou Deus os naturais diversos,

Um só Adão formou, e esse de nada.

Todos somos ruins, todos perversos,

Só nos distingue o vício, e a virtude,

De que uns são comensais, outros adversos."

(OC-II- p. 471)

Assim, é mesmo a caridade cristã e, num nível abaixo, a amizade, que exigem que os maus sejam amputados do corpo da República, de modo que sua corrupção não contamine outros, virtuosos e honestos.

Assim, se o homem tem capacidade inata racional e volitiva para entender os ditames da lei natural nele inscrita por Deus, também é certo que é criatura decaída, manchada pelo pecado original - como escreve Suarez, "paz e justiça não podem ser mantidas sem leis convenientes" porque "os homens individuais ordinários acham difícil entender o que é necessário para o bem comum e dificilmente fazem qualquer tentativa para atingi-lo por si próprios"14. Deve haver, desta maneira, uma conexão da lei natural, que Deus inscreve nas almas para que entendam seus desígnios e ajam segundo o livre-arbítrio, e a lei positiva, que os homens ordenam para si mesmos em função do governo das comu-

13 Cf. SÉNÈQUE. Traités philosophiques. Paris, Garnier, 1955. v.II.

14 Cf. SKINNER, Q. The revival of Thomism. In: The foundations of modern political thought. Cambridge, Cambridge University Press, 1978. v.2, p.160. 
nidades políticas que fundam. Em outros termos, as leis positivas devem ter a autoridade de leis genuínas - para tanto, devem ser compatíveis em todos os tempos com os teoremas da justiça natural fornecida pela lei natural. Esta fornece a moldura moral de todas as leis positivas. Basicamente, por isso, o fim da lei positiva é simplesmente evidenciar (in foro externo) uma lei superior que todo homem já conhece em sua consciência (in foro interno) (SKINNER, 1978, p. 149).

Tal doutrina, presente na sátira barroca seiscentista, faculta-lhe operar em dois sentidos: um deles consiste em denunciar o que passa por lei pelo fato de não estar caracterizado por tal justiça ou retidão natural, evidenciando que não tem força legítima para impor coisa alguma e que não deve ser obedecida jamais, como escreve Suarez. É, por exemplo, o teor das críticas contra os Governadores, acusados de tirania e, mais particularmente, o da maledicência contra Câmara Coutinho, cuja justiça nos enforcamentos se pauta pelo prazer de ver morrer:

\footnotetext{
"Enforcastes muita gente?

mente, quem tal coisa diz;

Gabriel os enforcava,

que eu com estes olhos vi.

E verdade, que gostáveis

vós muito de vê-los ir,

sois amigo de enforcados,

ter-lhes odio, isso fora ruim."

(OC-I- p. 215) 15
}

O outro sentido, complementar, consiste em denunciar aquelas açōes que infringem a lei positiva existente, tida como adequada expressão da lei natural - por exemplo, é esse o teor das sátiras aos religiosos luxuriosos, aos comerciantes usurários, aos cristâos-novos heréticos, aos feiticeiros idólatras, etc.

Em ambos os casos, evidencia-se como enunciado metaprescritivo da sátira a afirmação dos dominicanos e jesuítas contra-reformistas: sem a lei positiva para impor a lei natural, viver-se-ia um estado de total confusão. Por auto-interesse, segundo os mesmos juristas, os homens abrem mão de sua liberdade natural em função das limitaçōes da lei positiva - fazem-no movidos "a criar alguma autoridade pública cuja tarefa é manter e promover o bem comum" (SKINNER, 1978, p. 161). Por isso, ainda, a conceituação do direito como ius - "aquilo que é certo" - mas também como "umá certa capacidade moral que todos possuem". implica, na doutrina política dos juristas contra-reformistas, principalmente Suarez, uma reinterpretação da doutrina tomista tradicional do direito como lei objetiva. Segundo Skinner, a subjetivação da interpretação do direito, posta a funcionar para afirmar a luz inata da gráça divina contra o protestantismo e o maquiavelismo, implica também a questâo política da obediência ou não do súdito individual a um Príncipe tirano. Referindo-se à pessoa individual, parte do corpo político do Estado, Suarez escreve que é direito pessoal fundamental a manutenção da própria vida. Como em seu ataque papista às pretensōes do direito divino de James I da Inglaterra, afirma que "é legal a co-

Cf. também, no mesmo poema, estrofes 8, 9, 14, 16 etc. (OC-I- p.198-206). . 
munidade resistir contra seu príncipe, e mesmo matá-lo, se ela não tem outros meios de se preservar"' (Id. ibid., p. 176-77). Com restrições: se o governante nāo estiver engajado numa guerra agressiva destinada a destruir a comunidade $e$ a matar grande número de cidadāos, mas, "está meramente ferindo a comunidade por outros e menores modos... neste caso não há lugar para a defesa da comunidade seja pela força, seja pela traição, direcionadas contra a vida do príncipe" (Id. ibid.). Em outros termos, a comunidade deve sofrer em silêncio. A questão, portanto, presente nas críticas ao poder monárquico, é a de onde e quando tal direito de até matar o Príncipe pode vigorar. Suarez propóe assembléias representativas da vontade popular, só depois que a ação for discutida e aceita por várias cidades do reino, consultando-se os cidadãos, um ato de deposição pode ser legalmente executado. Não se pense, porém, que os padres contra-reformistas são democráticos: a doutrina visa, antes de tudo, a fortalecer a Santa Sé em sua ação contra os seguidores de Erasmo, Maquiavel e Lutero, além de opor-se às teses tradicionais do poder político, como as de Bártolo e Ockham, que teorizam o poder monárquico como delegação popular (Id. ibid, p. 179). Os contra-reformistas afirmam, como já se viu, que o poder monárquico não é delegação, mas quase alienaçāo do poder popular.

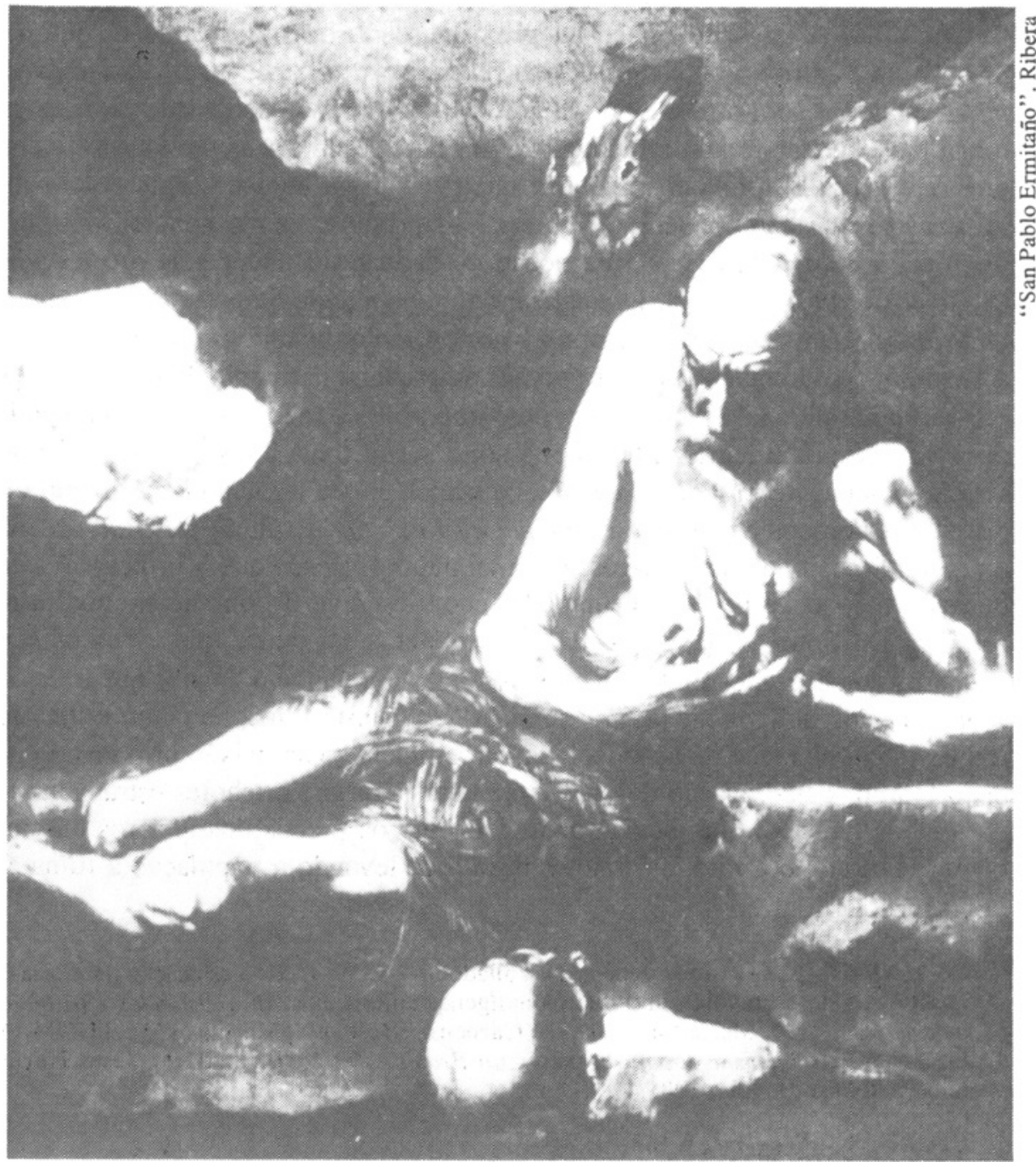


É nessè teatro monárquico que a sátira atua, determinando papéis para seus atores discursivos: ela também postula que as instituições são legais porque fundamentadas na legitimidade do poder da população quase alienado na pessoa do Rei, segundo um contrato que o faz cabeça do corpo político do Estado. Na ambigüidade da interpretação do que é natural e do que é positivo, oscila, identificando as inadequaçôes para sempre propor que a lei positiva é justa se é expressão da lei natural. Oscila, por exemplo, naturalizando uma convenção humanista, quando postula a inferioridade natural do gentio ou do herege, como ocorre na desqualificação dos Caramurus da Bahia, reduzidos à bestialidade, e dos cristãos-novos, aproximados do pecado mortal.

No Concílio de Trento e em Valladolid, em 1550, na conferência convocada por Carlos $\mathrm{V}$ para discutir a questão da conquista espanhola do Novo Mundo, Juan Ginés de Sepúlveda legitimou os massacres, defendendo a tese de que, desde que não possuíam nenhum conhecimento da fé cristã, os índios não poderiam estar vivendo uma vida de "genuína liberdade política e dignidade humana". A mesma argumentação, baseada em Aristóteles, constituía os índios como "escravos por natureza". Vivendo eles uma natural bruteza e inferioridade, a conquista espanhola seria uma guerra justa contra infiéis: sua escravização traduzia-se na economia de sua salvação pela conversão ao cristianismo ${ }^{16}$. É esta doutrina que permanece na sátira seiscentista, observando-se que não partilha da doutrina dos padres contra-reformistas, que nas teses de Sepúlveda viram analogia com a tese luterana herética de que toda sociedade política genuína deve fundar-se na divindade. Contra Sepúlveda e seus partidários, os padres da Contra-Reforma afirmam que qualquer grupo humano segue a lei natural, mesmo que não conheça a Revelação - portanto, como conclui Vitoria, é ilegítima a conquista baseada na noção de doação do poder pela graça divina (SKINNER, 1978, p. 169). Dramatizando o que a teologia propōe como contra naturam, porém, a sátira é ortodoxa - por exemplo, quando seu tema é a usura, a simonia, a sodomia - pois tais paixōes ameaçam a harmonia da lei natural expressa na harmonia do bem comum do corpo político, não havendo nenhuma lei positiva que possa legitimá-las. Por isso, a sátira toma como casos de sua invenção justamente os pontos de nāo-coincidência ou de não-cumprimento dos deveres recíprocos da relação corpo social-Rei e suidito individual-Rei, ordenada pela lei positiva como expressão da lei natural. Desde que o Príncipe é a cabeça de todo o corpo da comunidade, como escreve o dominicano contra-reformista De Soto ${ }^{17}$, ele "deve em conseqüência ser maior que todos os seus membros considerados juntos (maior universis)" e também "maior que todos os seus cidadãos individuais (maior singulis)". A sátira funciona como crítica feroz de toda veleidade de ação isolada, classificada como paixão próxima do pecado mortal, como a açāo dos comerciantes usurários, brichotes estrangeiros e mazombos baianos, que elevam artificialmente os preços dos gêneros básicos, como a farinha, o azeite, o vinho, o bacalhau, levando a população à ruína e à

Cf. HANKE, L. O grande debate de Valladolid - 1550-1551: a aplicação da teoria de Aristóteles de escravidão natural aos indígenas americanos. In: Aristóteles e os índios americanos. Trad. Maria Lúcia Galvão Carneiro. São Paulo, Martins. s/d e THOMAS, G. Política indigenista dos portugueses no Brasil 1500-1640. Trad. Pe. Jesus Hortal. São Paulo, Ed. Loyola, 1981. 
fome, que desestabilizam a concórdia e a paz do corpo político e que atingem, por isso mesmo, a cabeça desse corpo: Tais pessoas e ordens nâo têm como fim de sua ação a paz da República, mas a satisfação de seus próprios apetites ${ }^{18}$. Sua ação individual é tirânica. A sátira assume, por isso, função de integração política quando, advertindo contra a tirania, lembra a prescrição da harmonia de todas as partes da República. O tema da tirania, significando genericamente os apetites individuais, particulariza-se politicamente, em chave aristotélica, quàndo encenado na crítica aos governadores Sousa de Meneses e Câmara Coutinho:

" $O$ bem, que os mais bens encerra, e as glórias todas contém, é reinar, quem reina bem, pois figura a Deus na terra: eu cuido, que o mundo erra nesta alta reputação, que se o Rei erra uma ação paga a seu alto atributo um tristíssimo tributo, e misérrima pensāo.

\author{
O Príncipe soberano, \\ bom cristão temente a Deus, \\ se o não socorrem os céus, \\ pensōes paga ao ser humano: \\ está sujeito ao tirano, \\ que adulando ambicioso \\ é áspide venenoso, \\ que achacando-lhe os sentidos, \\ turbado o deixa de ouvidos, \\ de olhos o deixa ludoso." \\ (OC-I- p. 202) ${ }^{19}$
}

A sátira assume, por isso, função de integração polf́tica quando, advertindo contra a tirania, lembra a prescrição da harmonia de todas as partes da República.

Vários motivos das teorias jurídicas dos padres contra-reformistas concorrem neste trecho de sátira contra o Governador Antônio Luís Gonçalves da Câmara Coutinho, entre eles, o do providencialismo, o da divisāo da pessoa real em duas pessoas, o da soberania do poder real, o do povo vítima de um erro pessoal do Príncipe e, ainda, o da sua murmuraçāo justa contra um desacerto que o faz sofrer:

"Se fosse El-Rei informado, de quem o Tucano era, nunca à Bahia viera governar um povo honrado: mas foi El-Rei enganado, e eu com o povo o paguei, que é já costume, e já lei dos reinos sem intervalo, que pague o triste vassalo os desacertos de um Rei." (OC-I- p. 202)

Não considerar tais pressupostos jurídicos leva, geralmente, a interpretar a crítica da sátira como oposição nativista aos poderes constituídos, ação de uma

18 Este é o teor das críticas, por exemplo, aos comerciantes da Junta do Comércio, aos magistrados da Relação, aos Governadores e à Câmara.

19 Também as Décimas cuja didascália diz: "Na era de 1686 quimeriavam os sebastianistas a vinda do Encoberto por um cometa que apareceu. $O$ poeta pretende em vão desvanecê-los traduzindo um discurso do Pe. Antônio Vieira que se aplica a El- Rei D. Pedro II." Os versos finais são, aliás:

"que em prosa o compôs Vieira, traduziu em versos Matos".

(OC-V-p.1207-1211). 
consciência progressista ou possível contra os privilégios; ou ainda, como no caso dos versos "eu cuido, que o mundo erra/nesta alta reputação" contrapostos à teoria do direito divino dos reis, a interpretá-la como opośição libertina, herética ou libertária. $O$ que ocorre, porém, é que a sátira está perfeitamente integrada à ortodoxia teológico-política de sua época, podendo-se afirmar que o trecho acima é uma glosa da doutrina. Para mostrá-lo, é preciso inicialmente relativizar a noção de direito divino que, aplicada indistintamente ao século XVII ibérico, transpõe para ele formulações talvez válidas na França de Luís XIV ou na Inglaterra de James I, mas não em Portugal, onde a ação contra-reformista dos jesuítas e dominicanos está intensificada no mesmo século ${ }^{20}$. Não fazê-lo implica, como já se escreveu, postular um Gregório de Matos subversivo, profético da crise do sistema colonial, crítico da mesma monarquia em função de um desejo de liberação atual de seu intérprete.

Lutero, seguido de Melâncton e outros protestantes, afirma que, devido à Queda, a natureza humana corrompida não é capaz de entender a vontade do Deus Absconditus e, desta forma, de produzir um reflexo da justiça divina na ordenação da vida. A conclusão lógica é que os poderes que existem - e que devem necessariamente existir - foram diretamente ordenados por Deus aos homens para remediar a insuficiência moral da natureza humana corrompida. Os defensores da ragione di stato, identificados em Portugal como maquiavélicos, nāo pressupōem a natureza humana como dada pela Queda original, irremediavelmente corrompida, segundo os protestantes, perfectível, segundo os católicos, mas propõem o poder político como virtude da ocasião. Em outros termos, Lutero e Maquiavel coincidem, segundo os juristas contra-reformistas, porque ambos rejeitam a lei natural como base moral apropriada para a vida política. Sua crítica a eles visa a provar que é falsa a assunção maquiavélica de que o objetivo do Príncipe é a conservação de seu estado e de que, para tal fim, deve usar de todos os meios, bons e maus, justos e injustos, que possam assistilo (SKINNER, 1978, p. 143) ${ }^{21}$. Contra a hipocrisia maquiavélica, que prescreve que o Príncipe seja a raposa e o leão, afirmam que a "honestidade" (Id. ibid., p. 175) 22 católica é o maior poder para manter a paz e a felicidade políticas: o Príncipe deve ser, como no discurso da sátira, "bom cristão temente a Deus" socorrido "pelos céus". Contra a heresia luterana, cuja implicação política é a afirmação de que o Príncipe governa pela vontade divina para impor

20 Cf. MONCADA, L. C. Restauração do pensamento político português. In: Estudos de história do direito. Coimbra, Por Ordem da Universidade, 1948. v. I, p. 189-226. A Restauração de 1640 opõe a tese contra-reformista do tirano contra Castela, no sentido com que Suarez a teoriza quando trata da transferência do poder do povo para o Rei. A doutrina de Suarez faz clara distinçäo entre o rei e o tirano, garantindo ao povo o direito de resistência contra a opressão injusta. Veja-se o assento das Cortes gerais de 1641, que recebem o Duque de Bragança como Rei legítimo de Portugal: "Porquanto, conforme às regras do Direito natural e humano, ainda que os reinos transferissem nos reis todo o seu poder e império para os governarem, foi isso debaixo de uma tácita condição de o regerem e mandarem com justiça e sem tirania, e tanto que no modo de governarem e usarem deles podem os povos priva-los dos reinos em sua legítima e natural defensão, e nunca nestes casos foram vistos obrigarem-se, nem o vinculo do juramento estender-se a eles" (p. 216-217).

21 A crítica é de Ribadeneyra, citada por Skinner.

22 A "honestidade" É proposta por Suarez citada por Skinner. 
a lei e a ordem à natureza humana corrompida, os contra-reformistas retrucam com a doutrina da graça inata, pela qual os homens, certamente pecadores, são aptos não obstante para apreender a lei natural inscrita em suas almas pela vontade e inteligência divinas. Ao sublinhá-lo, o principal fim dos padres é repudiar a tese herética de que o estabelecimento da sociedade política é diretamente ordenado por Deus e, portanto, de que o Rei é infalível. Ao fazê-lo, reforçam a autoridade papal quando, por exemplo, repudiam como herética a tese de Marsilio de Pádua de que todo poder coercivo deve ser por definição secular. Vitoria, exemplifica Skinner, ataca aqueles que "isentam os governantes seculares da jurisdição da Igreja num tal grau que quase nada é deixado ao poder eclesiástico, e mesmo as causas espirituais são remetidas a cortes civis e decididas lá" (SKINNER, 1978, p. 179).

Assim, desde que "príncipes seculares são ignorantes da relação entre matérias espirituais e temporais, não podem ocupar-se da consideração de causas espirituais" (Id. ibid.). Em outros termos, se o Papa não tem nenhum poder direto de controlar os negócios seculares, tem poderes indiretos, muito extensos. Como Vigário de Cristo, tem a extensāo de seu poder limitada pelo modelo de Cristo. Criticando Lutero e reforçando os poderes do Papa, os juristas contra-reformistas demonstram a necessidade de se criar a sociedade política para afirmar que é realmente um erro postular que ela seja um dom de Deus e não uma convenção meramente humana ${ }^{23}$. A questão do contrato original entre população e Príncipe toma-se, assim, fundamental para os juristas da Contra-Reforma. É ela que está encenada na sátira, confirmando a solução dos padres.

Segundo Bártolo e Ockham, todo o poder conferido a um governante no momento da instituição de uma sociedade política foi-lhe conferido pelo povo. Este nunca confere ao governante poderes maiores que o que ele mesmo, povo, possui. Assim, ao transferir seus direitos para o Príncipe, este se torna uma espécie de reitor ou ministro da comunidade (SKINNER, 1978, p. 181). Contra tal doutrina, os contra-reformistas opōem a da transferência do poder como alienação - com ela, justificam a monarquia absoluta e a legalidade das instituiçōes monárquicas com restriçōes, como a do direito de desobediência do súdito se o contrato, baseado na lei natural, deixar de segui-la. Ao mesmo tempo, pela teoria do contrato, demonstram o erro das teses luteranas segundo as quais o poder monárquico é diretamente ordenado pela justiça divina.

O poder político pertence a priori e por direito natural (per ius naturale) ao povo como tal, isto $\hat{\epsilon}$, ao povo constituído como estado de natureza prévio

Segundo Bártolo e Ockham, todo o poder conferido a um governante no momento da instituição de uma sociedade política foi-lhe conferido pelo povo. Este nunca confere ao governante poderes maiores que 0 que ele mesmo, povo, possui. ao momento da transferência do poder. $O$ estado de natureza não é, segundo Suarez, uma comunidade de indivíduos, mas "um único corpo místico" no qual todos os membros reconhecem as mesmas obrigaçöes e "do ponto de vista moral são um único todo unificado"; em outros termos, têm uma única vontade unificada (SKINNER, 1978, p. 165). O estado de natureza (status naturae) corresponde à situação em que se encontraram todos os homens depois da Queda e antes da criação das sociedades políticas. Neste estado, todos eram livres e sem leis positivas. A ausência da lei positiva nāo significava ausência de lei, contudo, pois existia a lei natural. Os contra-reformistas, como Molina e Suarez, explicam que o homem escolheu perder a liberdade do estado de natureza para

Suarez o demonstra, comu se viu, pela doutrina da alienaçăo do poder. 
transformar-se em animal político, submetendo-se ao poder de outros porque sua vida seria marcada pela injustiça crescente se não o fizesse: a mancha do pecado original levaria à "total confusão". Por isso, a passagem do estado de natureza para a sociedade política consiste na constituição da lei positiva que impöe a lei natural, numa mescla muito contra-reformista, que no século XVII barroco é fundamental, de política e moral. Segundo Suarez, a soberania do Príncipe é recebida hic et nunc: sua autoridade pressupōe o povo corporificado e a vontade popular como mediação essencial do poder ${ }^{24}$. Em outros termos, fundamentais contra os luteranos, a autoridade política é sempre instituída por direito humano (de iure humano). Assim, Suarez escreve que é certamente permitido afirmar que todo poder provém de Deus, mas não que Deus confere imediata e formalmente um poder ao soberano. Deus é, escolasticamente, causa proxima et universalis, mas não causa próxima e imediata ("causa proxima, seu voluntate conferens talem potestatem") quando confere tal poder ao monar$\mathrm{ca}^{25}$. O mesmo Suarez, ainda, teoriza o absolutismo: "Tal transferência de poder da república para o príncipe não é delegação mas quase alienação, ou um perfeito abandono do poder que estava na comunidade"26. A transferência do poder é tão próxima da total alienação - quasi alienatio - que se deixa interpretar analogicamente segundo o modelo jurídico da escravidâo:

"(...) assim quando um homem particular se vende e se entrega a outro como escravo, este dominium é puramente e simplesmente instituído pelo homem. Com efeito, estando suposto este contrato, o escravo é obrigado, por direito divino como por direito natural, a obedecer a seu mestre. Da mesma forma, o poder (potestas), tendo sido transferido ao rei, este é feito por ele superior ao reino que o deu a ele, porque, dando-se a ele, o reino se submeteu como súdito (se subjecit) e privou-se da liberdade anterior, como se conclui, guardadas as proporções, do exemplo da escravidão" 27 .

24 Em 1614, livros de Suarez são queimados na França. Cf. RICHELIEU, Mémoires. Année 1614: "Environ ce temps, le Parlement fit brûler, par la main du bourreau, un livre de Suarez, jésuite, intitulé La defense de la foi catholique, apostolique, contre les erreurs de la secte d'Angle terre, comme enseignant qu'il etoit loisible aux sujets et aux étrangers d'attenter à la personne des souverains". Cf. CORNETTE, J. L'état baroque dans la France du premier XVIlè siècle - une approche par la chronologie. In: MÉCHOULAN, H., org. L'État Baroque 1610-1652. Paris, VRIN, 1985. p. 463.

25 SUAREZ citado por COURTINE, op. cit., p.98.

26 Como muito bem demonstra Courtine em seu estudo excelente, não há possibilidade de tratar uniformemente as doutrinas do direito divino dos reis - por exemplo, na França, Jurieu propõe a necessidade de um pacto mútuo entre o povo e o soberano, assim como Bossuet, por exemplo, certamente se alinharia com James I, contra Suarez, segundo seu galicanismo explicitado no $1^{\circ}$ artigo da declaração de 1682 que, entre outras coisas, diz: "Celui donc que s'oppose aux puissances résiste à l'ordre de Dieu. Nous déclarons en consequence que les Rois et les Souverains ne sont soumis dans les choses temporelles à aucune puissance ecclésiastique par l'ordre de Dieu; qu'ils ne peuvent être déposés directement ni indirectement par l'autorité des chefs de l'Eglise; que leurs sujets ne peuvent, au nom de cette même autorité, être dispensés de la soumission et de l'obéissance qu'ils leur doivent, ou absous du serment de fidélité; et que cette doctreine, nécessaire pour la tranquillité publique, et non moins avantageuse à l'Eglise qu'à l'Etat, doit être inviolablement gardée come conforme à la parole de Dieu, à la tradition des saints Pères et aux exemples des saints." (op. cit., p. 115).

27 SUAREZ, De legibus, III, IV, 6 citado por COURTINE, op. cit., p. 115. 
Ao teorizar o poder monárquico como transferência de poder da populaçāo para o Príncipe, os juristas contra-reformistas, principalmente Suarez, repudiam também duas interpretaçōes políticas tradicionais na Europa catolica.

A primeira é a tese dos canonistas, pela qual o poder político é divinamente conferido a um príncipe particular, devendo sempre continuar em uma pessoa particular por um processo de sucessão hereditária. Segundo Suarez, tal tese esquece que "é essencial que o primeiro detentor deva ter derivado seu poder supremo imediatamente da comunidade; de modo que seus sucessores, menos diretamente mas ainda fundamentalmente, devem ainda derivar seu poder da mesma origem" 28 . A implicaçāo da postura contra-reformista é a de que um direito de sucessāo nāo pode ser de fato a fonte básica do poder de um príncipe, reforçando-se ainda uma vez a tese da transferência do poder da comunidade para o governante. A outra tese é a dos imperialistas, pela qual há um príncipe particular com domínio temporal através de todo o mundo. Baseado em sua teoria da transferência do poder, Suarez escreve que isto é uma "impossibilidade moral", pois a condição para existir tal poder é a de tê-lo recebido dos homens e "nunca aconteceu que homens tenham alguma vez consentido em conferir tal poder ou em instituir tal única cabeça sobre eles mesmos". A implicaçāo da tese de Suarez é a de que, mesmo se existisse, um Império universal seria ilegítimo. Central em todas as críticas e retificaçōes dos contra- reformistas é, assim, a doutrina da transferência do poder.

Se a comunidade transfere o poder para constituir uma sociedade política, cria o poder do Imperium acima dela - o poder do Rei - de fazer leis e manejar a espada da justiça, como recita a sátira:

"que o mau na própria cabeça

traga a justiça aprendida."

(OC-I- p.205)

Em outros termos, o momento da constituição da sociedade política é também o da constituição do poder "pela força da razão natural" (SKINNER, 1978, p. 181). Skinner demonstra que, segundo a interpretação tradicional de bartolistas e ockhamistas do poder como delegação, a comunidade pode obrigar o governante a cumprir as leis positivas. Proposta a teoria da transferência - quasi alienatio - do poder, os contra-reformistas demonstram a impossibilidade lógica de tais exigências populares: desde que o Príncipe não tem supe-

Ao teorizar o poder monárquico como transferência de poder da população para o Príncipe, os juristas contra-reformistas, principalmente

Suarez, repudiam também duas interpretaçōes políticas tradicionais na Europa cat6lica. rior, como escreve Suarez, não há ninguém que possa obrigá-lo a nada - mesmo que se afirme que, em consciência, ele deveria seguir as leis que promulga. O Príncipe é legibus solutus, livre do poder coercitivo e das leis positivas. $\mathrm{O}$ que o Príncipe, "bom cristão temente a Deus", deve fazer é seguir a lei natural para que sua açāo seja legítima. Por isso mesmo, "se um reino surgir baseado em meios injustos, o governante não possui nenhuma autoridade legislativa legítima " (Id. ibid., p. 163). Ou ainda, como escreve Bellarmino, "uma lei civil justa é sempre uma conclusão da divina lei moral" 29 . Por isso, ainda, a interpretação do poder real como transferência é dirigida contra Lutero: segundo Suarez, ao afirmar o direito, em certas circunstâncias, de desobedecer às ordens

\footnotetext{
28 Cf. SKINNER, op. cit., p. 164.

29 Cf. SKINNER, op. cit., p. 167. SKINNER, op. cit., p. 167.
} 
emanadas de um governante legítimo, a heresia luterana está com efeito afirmando que é possível desobedecer à lei natural. Ora, qualquer um que se desvia seja da lei natural ou positiva, divina ou humana, deve, em qualquer caso, estar pecando contra a eterna lei de Deus, como escreve Bellarmino ${ }^{30}$. A posição luterana torna-se, assim, não apenas erro, mas blasfêmia. Observe-se, aqui, uma das razōes doutrinais da intensa sacralização do poder político pela arte e literatura barrocas no século XVII: desde que a lei natural é também a vontade de Deus, os preceitos e as proibiçōes das leis positivas divinas da Bíblia não podem diferir dos preceitos da lei natural, estando contidos nela. Por isso, qualquer código legal genuíno deve incluir todos os preceitos e proibiçóes feitos por Deus no Decálogo.

A potência do Príncipe é absoluta porque se constitui formalmente da inteira submissão dos súditos. $O$ que define a soberania é a sujeição completa dos súditos que - sendo legítimo o Príncipe - abrem māo de todos os direitos para em troca receber os privilégios, temporários e sempre revogáveis pela vontade soberana do Rei 31: "que o cair é dos validos", como diz a sátira nas "Décimas" em que se censura o Conde de Ericeira, D. Luís de Meneses, que se suicidou atirando-se de uma janela:

"Tinha o Conde de morrer; todo o mortal nisto pára, e se ele se não matara, quem lho havia de fazer? fez bem o Conde a meu ver, quando ao jardim se arrojou, e entre as flores expirou: vento é a vida em rigor, e como o Conde era flor, entre as flores acabou.
Se ignorou alguns sentidos, porque tanto mal se urdiu, era valido, e caiu, que o cair é dos validos: tão certos são, e sabidos no monte, no lar, na praça estes reveses da graça, que é já dos Palácios lei, que quem da graça d'El-Rei cai, cai da sua desgraça." (OC-I- p. 143-144)

A sátira seiscentista encena esse ponto de igualdade de todos na submissão da transferência do poder, pela qual os membros do corpo político são cidadãos e, portanto, súditos. Neste mesmo sentido, a igualdade simbólica da submissão homogênea de todos pelo contrato é desigualdade real dos privilégios de alguns, segundo a vontade soberana que escalona os súditos em ordens, hierarquicamente, e que ao mesmo tempo os guia como cabeça do corpo político. Dificuldade, aqui, do conceito de propriedade privada: segundo a doutrina escolástica tradicional, o direito à propriedade é parte da lei natural. Segundo os juristas contra-reformistas, se a lei das nações é apenas lei positiva, o direito

30 Cf. SKINNER, op. cit., p. 168.

31 Como escreve Bodin: "Quando o chefe de família sai de sua casa onde comanda para tratar e negociar com os outros chefes de família aquilo que lhes toca a todos em geral, então ele se despoja do título de mestre, de chefe, de senhor, para ser companheiro, par e associado dos outros; deixando sua família para entrar na Cidade, e os negócios domésticos para tratar dos negócios públicos: em vez de senhor ele se chama cidadão" (COURTINE, op. cit., p. 105). Bodin também escreve que: "C'est la reconnaissance et obéissance du franc sujet envers son Prince souverain, et la tuition, justice et défense du Prirce envers le sujet, qui fait le citoyen" (Id. ibid., p. 117). 
A sátira seiscentista encena esse ponto de igualdade de todos na submissão da transferência do poder, pela qual os membros do corpo político são cidadãos e, portanto, súditos. à propriedade deve ter sido estabelecido inicialmente por uma autoridade também apenas humana. Portanto, o direito dos proprietários poderia ser alterado e abolido a qualquer momento, sem ferir diretamente os princípios da lei natural. A conseqüência é, obviamente, subversiva. Assim, os juristas alegam que o direito à propriedade deve ser um direito natural, não um simples privilégio derivado da lei positiva (SKINNER, 1978, p. 153). Ou, como escreve Suarez, se a posse comunitária se opóe à particular e se isso pode ser uma injunção da lei natural, é, contudo, apenas uma injunçāo negativa, servindo para lembrar que "toda propriedade deveria ser possuída em comum pela força desta lei se não tivesse ocorrido que os homens decidissem introduzir um sistema diferente" (Id. ibid., p. 1534). Em outros termos, a lei natural pode ser avocada tanto para sancionar a continuidade quanto a abolição da propriedade comunitária e, assim, a decisão de dividir a propriedade é deixada para a decisão da lei positiva, mas de tal forma que a decisão de instituir a própria divisão não é um mero aspecto da lei positiva. Interpretando a concessão do privilégio, tal doutrina implica que o privilégio é uma lei positiva, que pode ser revogada a qualquer momento, segundo o casuísmo das interpretaçōes, mas que, ao concedê-lo ou retirá-lo, o Rei se pauta pela lei natural.

A sátira desenvolve como um de seus temas principais esta desigualdade de direito para ratificá-la como harmonia preestabelecida e criticar atos que publicamente a desestabilizam quando infringem os deveres de cada ordem: não se critica, portanto, o privilégio, mas os efeitos de seu excesso ou de sua carência. Tanto o excesso quanto a falta ameaçam a concórdia do bem comum, desordenando a harmonia das partes do corpo político. Segundo a sátira, a desigualdade é natural, pois adaptada ao fim superior da paz social. As ordens, assim como cada indivíduo, devem contentar-se com o que são e com o que fazem, em função do bem comum.

Em outros termos, a virtude moral é sempre virtude política, porque é a vontade real que, sendo legítima, expressa nas leis positivas aquilo que é lícito ou ilícito conforme a lei natural - como o Papa, cuja plenitudo potestatis decorre de ser o Vigário de Cristo: contestá-lo é sacrilégio, tanto quanto ousar restringir a potência de Deus ${ }^{32}$. Assim como o Papa se quer Vicarius Christi, os reis do século XVII afirmam-se vigários de Deus: são deuses ${ }^{33}$, observándo-se que a doutrina contra-reformista não se opõe ao absolutismo, mas o retifica para introduzir a questão do contrato, como transferência do poder, e, legitimando o poder real, propô-lo como expressão da lei natural - em outros termos, como metáfora expressiva do divino, quando legítimo o contrato. Virtude, honra e

32 Declaração de Urbano VI: “omnia possum et ita volo!".

33

Cf. BOSSUET apud COURTINE, op. cit., p. 111: "Vous êtes des dieux (...) Mais ô dieux de chair et de sang, ô dieux de terre et de poussière, vous mourez comme des hommes. N'importe, vous êtes des dieux, encore que vous mourriez, et votre autorité ne meurt pas; cet esprit de royauté passe tout entier à vos successeurs... L'homme meurt, il est vrai, mais le roi, disons-nous, ne meurt jamais: l'image de dieu est immortelle" ( 2 de abril de 1662). Cf. ainda, trecho de carta de James I, de Inglaterra, a seu filho: "É-vos preciso acima de todas as coisas aprender a conhecer e a amar a Deus a quem deveis dupla obrigação: primeiramente por vos haver feito homem e em seguida porque fez de vós um pequeno deus pará sentar-se sobre seu trono e reinar sobre os outros homens". (Id. ibid., p. 107). 
glória são os corolários dessa doutrina que, desde o século XVI, vinha sendo minada pelo maquiavelismo e, mais tarde, pela teoria de Hobbes sobre a universalidade do auto-interesse na condução da coisá pública. Passando ao largo dessas críticas, a sátira barroca seiscentista postula virtude, honra e glória em termos de sua concepção tradicional e providencialista.

A tradição humanista produz duas concepçōes principais sobre a virtù ética e política. Por uma delas, a virtude é uma qualidade que capacita o governante a atingir seus fins mais nobres. A outra, complementar, afirma que a posse da virtù pode ser equiparada à posse de todas as virtudes maiores (SKINNER, 1978, p. 131). Segundo a renovaçāo escolástica, se um príncipe deseja manter seu estado e alcançar a honra, a fama e a glória, deve acima de tudo cultivar o elenco completo das virtudes morais e cristās, donde a proliferação, nos séculos XVI e XVII, dos textos que reativam o estoicismo - Marco Aurélio, Sêneca - fundindo-o com os exempla da tradição patrística e medieval, Maquiavel propōe que o alvo do Príncipe é, efetivamente, a honra, a glória e a fama, rejeitando a crença dominante de que o meio seguro para alcançá-las ou mantê-las é um meio virtuoso. Para agir sempre virtuosamente, não se deve ser virtuoso o tempo todo. Nada mais importante que manter as aparências porque "o golfo existente entre o como se deveria viver e o como se vive é tão largo que um homem que negligencia o que realmente é feito pelo que deveria ser feito aprende o caminho da autodestruição antes que o da autopreservação" (MAQUIAVEL, 1961, p. 91). Numa política maquiavélica, ainda, a sátira como variedade da murmuração - poderia, até certo limite, ser perfeitamente tolerada e mesmo incentivada pelo Príncipe, pois manteria em evidência sua pessoa - fama - evidenciando também sua magnanimidade... Assim, a crítica às virtudes tradicionais ${ }^{34}$ propōe que o Príncipe deve ver que é essencial, positivamente vantajoso, agir contrariamente à boa fé, à caridade, à bondade, à religião. Inversão divertida; há imensa utilidade política nos vícios que os Leais Conselheiros, galateos e espelhos de príncipes, oráculos manuais e artes de prudência, comuníssimos nos séculos XVI e XVII, descrevem e propōem sejam evitados; a avareza, a fraude, a mentira, a crueldade são virtudes básicas para governar. Não se trata, como escreve Skinner, de uma diferença entre uma visão moral da política e uma visão da política divorciada da moralidade, pois o contraste essencial é antes entre duas moralidades políticas diferentes e inimigas (SKINNER, 1978, p. 135). Não seria preciso talvez lembrá-lo, mas a política católica dos reis ibéricos realiza, muitas vezes, a virtù maquiavélica de maneira exemplar: citem-se, como exemplo, a ação de Felipe II nos Países Baixos, o episódio da anulação do casamento de D. Afonso VI e D. Maria Francisca de Sabóia e o casamento desta com o príncipe D. Pedro, irmão do rei, em 28 de março de $1668^{35}$.

34 A crítica se faz, principalmente, em "16 - De Liberalitate et parsimonia", "17 - De crudelitate et pietate" e "18 - Quomodo fides a princibus sit servand". Ver MAQUIAVEL, The Prince, (1961).

35 Cf., por exemplo, DÓRIA, A. Á. A rainha d. Maria Francisca de Saboia (1646-1683). Ensaio biográfico. Porto, Livraria Civilização, 1944 e HANSON, C. A. Pedro, o "Pacífico". In: Economia e sociedade no Portugal Barroco 1668-1703. Lisboa, Publicaçöes Dom Quixoté. 1986.
A tradição humanista traduz duas concepçöes principais sobre a virtù ética e polf́tica. Por uma delas, a virtude é uma qualidade que capacita - governante a atingir seus fins mais nobres. A outra, complementar, afirma que a posse da virtù pode ser equiparada a posse de todas as virtudes maiores. 


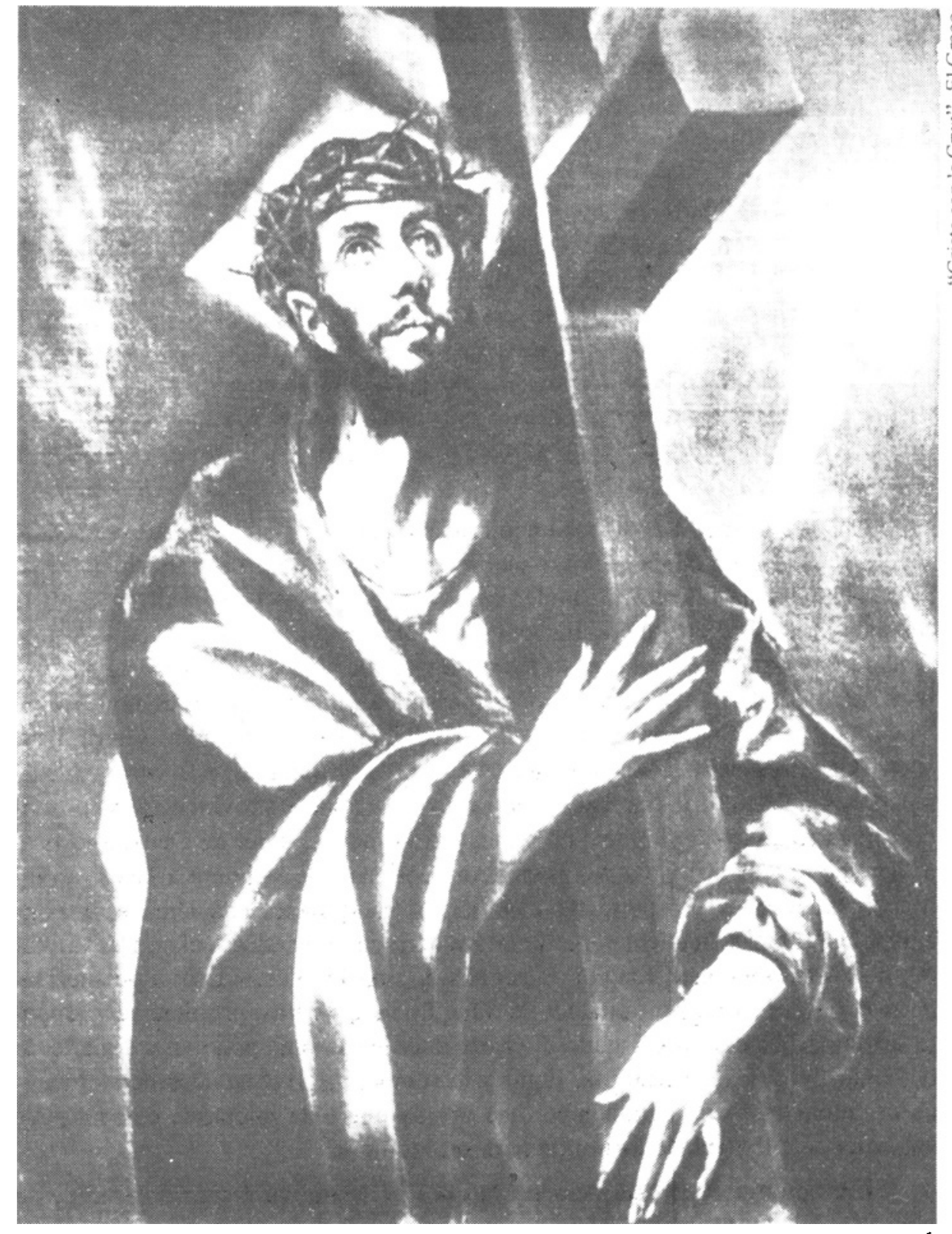

É preciso lembrar, ainda, que a reativação da escolástica aplica um ésquema tipológico à figura do Rei: assim como o Cristo é, em sua humanidade, instrumento da divindade (instrumentum divinitatis), também o Rei é proposto duplamente, como sendo o que é por aquilo que está nele mesmo e além dele mesmo. Tem duas pessoas: persona personalis; mortal, e persona: idealis (mystica, ficta). Os dois corpos do Rei permitem, entre outras coisas, afirmar a perpetuidade do poder e seu absoluto: para além da sucessão temporal dos reis, homens mortais e falíveis, a potência pública permanece imutável em sua identidade sagrada 36 . A dupla pessoa aplica-se à esfera-do poder político: este

36 Cf. BALDO. "Dignitas (Majestas) regia nunquam moritur", citado por COURTINE, op. cit., p. 102. 
é ordinário, contorne se trate do direito privado, quando se tem $\mathrm{cm}$ vista o interesse particular dos súditos, e absoluto, quando se exerce em vista do bem comum e se determina em funçâo da razão de Estado.

A sátira opera sempre na circunscriçāo do poder ordinário, tendo por pressuposto da crítica o poder absoluto da razão de Estado soberana. Desta forma, coisa não vista pelas interpretaçōes que postulam o nacionalismo ou a libertinagem de Gregório de Matos, pode até contestar, em função de interesses particulares de grupos ou de súditos individuais, determinadas ordens e imposiçóes. Não contesta, porém, a razão de Estado que determina os excessos ou as carências, nem seu fundamento, a soberania e a mística real. Por isso, a intervenção incide sempre sobre abusos em questóes do poder ordinário, porque o pressuposto da intervenção é o uso estabelecido sempre alegado e, mais, o bom uso - e este se encontra pré-formado na vontade da persona mystica do Rei, que é intocável, sagrada. Como se leu, o ius é sempre lei natural expressa em leis positivas - portanto, Razão.

Os vários topoi teológicos encontráveis na sátira e em outros discursos do século XVII, como os da oratória sacra, têm assim - antes de serem mera ornamentação de uma retórica do poder voltando, como se costuma dizer, à Idade Média - uma função determinante na elaboração e confirmaçāo do conceito moderno de poder soberano absoluto. Gregório de Matos e Guerra está na doutrina teologico-política e seus topoi perpassam a obra de autores como Lope de Vega, Quevedo, Saavedra Fajardo, Gracián, Calderón de la Barca, Vieira, Bossuet. Por vezes opondo a soberania do Estado e a Santa Sé, por vezes aproximando-os num mito indiscernível de razão de Estado e providencialismo divino, prega-se a virtude do ideal ou o ideal da virtude. $O$ amor de Deus, a justiça, a verdade, a concórdia e a paz permitem, teoricamente, a honra a Deus, a dignidade honrosa, a prosperidade material, a tranqüilidade da alma e os bons exemplos, tópicas freqüentes na literatura barroca parenética e elegíaca. Contudo, a mesma dignidade contém os germes do orgulho desmedido; a prosperidade material, da cobiça e fatuidade; a tranqüilidade da alma propicia ocasiāo para maquinaçōes contra o Estado e mesmo o bom exemplo pode vir a ser arte do demônio, glorificação maligna. Equilíbrio sempre instável na desordem dinâmica de tudo, intervém a prudência, que afirma que toda iniciativa pessoal deve submeter-se à legalidade instituída para ser legítima.

Um epitáfio composto para o Marquês de Marialva é significativo dessa unidade de integração visada pela sátira, e que é dominante no século XVII ibérico:
"Em três partes enterrado está o corpo do Marquês de Marialvâ: porque em dez mil seu nome é venerado: e foi destino acertado, que em tanta parte estivesse, para que o mundo soubesse, que este valeroso Marte morto assiste em qualquer parte, como se ainda vivesse."
(OC-I- p. 150)

A sátira opera sempre na circunscrição do poder ordinário, tendo por pressuposto da crítica o poder absoluto da razão de Estado soberana. 
O mesmo topos "todo/parte" aqui é desenvolvido: as partes de Marialva, enterradas em lugares diferentes, alegorizam a mesma unidade do corpo político, da qual ele, como fidalgo, é exemplar: nele a honra, a glória e a fama, sintetizadas no epíteto "valeroso Marte".

Assim, a exemplo do que ocorre com a Biblia católica, não se admite o livre exame também em política por parte dos súditos, mas uma concordada consonância, obediência e repetição de padrōes estabelecidos ${ }^{37}$. Entre outros fins, a arte barroca articula-se como dirigismo pedagógico, educação do gosto por meio do mito épico: cada qual se contente com o seu, faça cada um o seu papel, no lugar e na ordem em que, como parte, está colocado no corpo político do Estado. Apologia da cabeça, portanto, que sabe o seu papel sabendo os papéis das partes no todo ${ }^{38}$ :

"Con este fin (de mantener la unión) ponen todas sus fuerzas los reyes de España en que los pueblos, reinos y estados a ellos sujetos se amen entre sí con la unidad de la católica religión, no permitiendo vivir con ellos judio, moro, ni hereje alguno que pueda ser parte ni impidimento para desatar este lazo de unión. En orden a esto, han instituido tantos Estudios y Universidades, en especial la muy florida de Salamanca, y dotado em ellas tan grande número de cátedras, donde florecen y resplandecen tanto las letras en todas ciencias, como hacen fe los eminentes hombres que cada dia estampan tan ingeniosas y eruditas obras, asi en Teologia y Leyes como en todas las demás ciencias y facultades; los predicadores insignes, que con singular honor suyo y colmado fruto de los oyentes, ocupan y ejercitan los púlpitos; los maestros y doctores, pozos de ciencia que, como por semilla, retienen en si las Universidades para que se continúe en ellas la enseñanza y doctrina. Con este escuadrón de le-

37 Cf. SAAVEDRA FAJARDO, Diego - "Empresa XXVII". In: Empresas Políticas. Ed. Quintin Aldea Vaquero. Madrid, Ed. Nacional, 1976, 2 v., v. I: "Quando o povo começar a opinar em religiāo e quiser introduzir novidades nela, é preciso aplicar logo o castigo, e arrancar pela raiz a má semente antes que cresça e se multiplique (...)". Lembre-se ainda que, no século XVII ibérico, a liberdade de consciência é equiparada ao maquiavelismo. Cf., também, RICHELIEU - Testament politique $(\mathrm{I}, 4)$ In: CORNETTE, Joël - "L'état baroque dans la France du premier XVIIè siècle - une approche par la chronologie" In: MÉCHOULAN, Henry (org.) - L'État Baroque 1610-1652. Paris, Vrin, 1985, (Années 1629-1630), p. 470:

"Tous les politiques sont d'accord que si les peuples stoient trop à leur aise, il seroit impossible de les contenir dans le règles de leur devoir; leur fondement est qu'ayant moin de connaissance que les autres ordres de l'État beaucoup plus cultivez ou instruits, s'ils n'etoient retenus par quelque necessite, difficilement demeureroient-ils dans les règles qui leur sont prescrites par la Raison et par les Loix. La Raison ne permet pas de les exempter de toutes charges parce qu'en perdant en tel cas la marque de leur sujettion, ils perdroient aussi la mémoire de leur condition et que s'ils stoient libres de tributs, ils penseroient l'être de l'obéissance. Il les faut comparer aux mulets qui étant accoutumez à la charge se gâtent par un long repos plus que par le travail; mais ainsi que le travail, doit être modéré, et qu'il faut que la charge de ces animaux soit proportionnée à leurs forces, il en est de même des subsides à l'égard des peuples s'ils n'étoient modérés, lors même qu'ils seroient utiles au public, ils ne laisseroient pas d'être injustes."

38 As afirmaçōes de Salazar são generalizáveis para Portugàl no século XVII. Neste plano de mando, por exemplo, a Inquisição funciona acoplada ao póder de Estado. 
trados, que son por la mayor parte religiosos o eclesiásticos seglares (a quienes los católicos Reyes, por el respeto que les tiene, gracias y mercedes que les hacen, tienen de su parte), fortifican su imperio y monarquia, no menos que con los presídios y tercios de soldados; porque llana cosa es que en um imperio tan grande y de naciones tan diversas fuera fácil resbalar unas a otras en alguna ocasión de disgusto contra el príncipe, teniendo cabeza a quien seguiesen; y es también cierto que quien las tiene sujetas y rendidas y obedientes al superior, son los hombres doctos y eclesiásticos, en especial los religiosos y predicadores, a quienes dan crédito por la promessa que les hacen de los eternos bienes, y por el desprecio que ven en ellos en sus acciones y vidas de los caducos y temporales; de suerte que predicando ellos continuamente al pueblo que es voluntad de Dios obedecer a los reyes, y que a los trabajos y miserias que se padecen en esta vida corresponderá en la otra eterno premio y amenazando asímismo de ordinario en los confesionarios y púlpitos con la divina justicia humana a los homicidas, ladrones, sensuales, rebeldes y sediciosos, y confirmando a los buenos y virtuosos (por otra parte) con la esperanza de la eterna felicidad, que es la perenne y clara vista de Dios, no hallan los desalmados y perdidos quien se junte a ellos, ni quien siga su parecer y opinión, ni pueden unirse con ellos muchos de la república, en cuyas manos está la fuerza, aunque lo deseen, ni brotan la ponzoña, aunque estean avenenados." (SALAZAR apud FERROL, 1957, p. 232-33.)

\section{Referências Bibliograficas}

FERROL, F. M. 1957. Saavedra Fajardo y la políica del Barroco. Madrid, Instituto de Estudios Políticos.

MAQUIAVEL, N. 1961. The prince. Harmondsworth.

SAAVEDRA FAJARDO, D. 1957. Corona Gótica. In: FERROL, F. M. Saavedra Fajardo y la política del Barroco. Madrid, Instituto de Estudios Políticos.

1976. Empresa XCI. In: Empresas políticas. Ed. Quintin Aldea Vaquero, Madrid, Nacional. 2v.

SALAZAR, F. J. 1957. Política española. prop. 5, III. In: FERROL, F. M. Saavedra Fajardo y la política del Barroço. Madrid, Instituto de Estudios Políticos.

SANTO TOMÁS, 1952. Summa theolog. III, 9, VIII, a.1. In: The summa theologica of Saint Thomas Aquinas. Translated by fathers of the English Dominican Province. London, Encyclopaedia Britannica, Inc. $2 v$.

1957 a. Lectio 2 ad Rom. XII. In: FERROL, F. M. Saavedra Fajardo y la politica del Barroco. Madrid, Instituto de Estudios Políticos.

1957 b. Lectio 3 ad Corinth. XII. In: FERROL, F. M. Saavedra Fajardo y la política del Barroco. Madrid, Instituto de Estudios Políticos.

SKINNER, Q. 1978. The foundations of modern political thought. Cambridge, Cambridge University Press. v.2.

João Adolfo Hansen é professor de Literatura Brasileira no Departamento de Letras Clássicas e Vernáculas da FFLCH/USP. 